\title{
Front Matter: Volume 6993
}

, "Front Matter: Volume 6993," Proc. SPIE 6993, MEMS, MOEMS, and Micromachining III, 699301 (12 May 2008); doi: 10.1117/12.797940

SPIE. Event: SPIE Photonics Europe, 2008, Strasbourg, France 


\title{
PROCEEDINGS OF SPIE
}

\section{MEMS, MOEMS, and Micromachining III}

\author{
Hakan Urey \\ Editor
}

9-10 April 2008

Strasbourg, France

Sponsored by

SPIE Europe

Cosponsored by

Alsace International (France)

Conseil Général du Bas-Rhin (France)

Région Alsace (France)

Communauté Urbaine de Strasbourg (France)

Cooperating Organizations

AFOP_Association Française des Industries de l'Optique et de la Photonique (France)

EOS-European Optical Society (Germany) • EPIC-European Photonics Industry Consortium

(France) • ePIXnet (Belgium) • IOP-Institute of Physics (United Kingdom) • NEMO-Network of

Excellence on Micro-Optics (Belgium) • OLAS (Italy) • The OLLA Project (Germany) • OPERA 2015

(Belgium) • PhOREMOST (Ireland) • Photonics Knowledge Transfer Network (United Kingdom)

Photonics Cluster (United Kingdom) • Photonics4Life (Germany) • Photonics 21 (Germany)

RhenaPhotonics Alsace (France)

Published by

SPIE

Volume 6993

Proceedings of SPIE, 0277-786X, v. 6993 
The papers included in this volume were part of the technical conference cited on the cover and title page. Papers were selected and subject to review by the editors and conference program committee. Some conference presentations may not be available for publication. The papers published in these proceedings reflect the work and thoughts of the authors and are published herein as submitted. The publisher is not responsible for the validity of the information or for any outcomes resulting from reliance thereon.

Please use the following format to cite material from this book:

Author(s), "Title of Paper," in MEMS, MOEMS, and Micromachining III, edited by Hakan Urey, Proceedings of SPIE Vol. 6993 (SPIE, Bellingham, WA, 2008) Article CID Number.

ISSN 0277-786X

ISBN 9780819471918

Published by

SPIE

P.O. Box 10, Bellingham, Washington 98227-0010 USA

Telephone +1 3606763290 (Pacific Time) · Fax +1 3606471445

SPIE.org

Copyright (C 2008, Society of Photo-Optical Instrumentation Engineers

Copying of material in this book for internal or personal use, or for the internal or personal use of specific clients, beyond the fair use provisions granted by the U.S. Copyright Law is authorized by SPIE subject to payment of copying fees. The Transactional Reporting Service base fee for this volume is $\$ 18.00$ per article (or portion thereof), which should be paid directly to the Copyright Clearance Center (CCC), 222 Rosewood Drive, Danvers, MA 01923. Payment may also be made electronically through CCC Online at copyright.com. Other copying for republication, resale, advertising or promotion, or any form of systematic or multiple reproduction of any material in this book is prohibited except with permission in writing from the publisher. The CCC fee code is $0277-786 \mathrm{X} / 08 / \$ 18.00$.

Printed in the United States of America.

Publication of record for individual papers is online in the SPIE Digital Library.

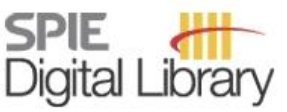

SPIEDigitallibrary.org

Paper Numbering: Proceedings of SPIE follow an e-First publication model, with papers published first online and then in print and on CD-ROM. Papers are published as they are submitted and meet publication criteria. A unique, consistent, permanent citation identifier (CID) number is assigned to each article at the time of the first publication. Utilization of CIDs allows articles to be fully citable as soon they are published online, and connects the same identifier to all online, print, and electronic versions of the publication. SPIE uses a six-digit CID article numbering system in which:

- The first four digits correspond to the SPIE volume number.

- The last two digits indicate publication order within the volume using a Base 36 numbering system employing both numerals and letters. These two-number sets start with 00, 01, 02, 03, 04, 05, $06,07,08,09,0 A, 0 B \ldots 0 Z$, followed by $10-12,20-2 Z$, etc.

The CID number appears on each page of the manuscript. The complete citation is used on the first page, and an abbreviated version on subsequent pages. Numbers in the index correspond to the last two digits of the six-digit CID number. 


\section{Contents}

vii Conference Committee

SESSION 1 MOEMS DEVICES AND SYSTEMS I

699302 NEMS/MEMS cantilever-based biosensors: addressing the open issues (Invited Paper) [6993-01]

Y. Nemirovsky, A. Shemesh, S. Stolyarova, Technion-Israel Institute of Technology (Israel)

699303 Magnetic actuated FR4 scanners for compact spectrometers [6993-02]

Ç. Ataman, H. Urey, Koç Univ. (Turkey)

699304 Micromachined multicavity grey body emitter for the use in MIR spectroscopic systems [6993-03]

J. Hildenbrand, A. Kürzinger, E. Moretton, Fraunhofer-Institute for Physical Measurement Technique (Germany); A. Greiner, Univ. of Freiburg (Germany); A. Lambrecht,

J. Wöllenstein, Fraunhofer-Institute for Physical Measurement Technique (Germany);

J. G. Korvink, Univ. of Freiburg (Germany)

699305 Optimisation and characterisation of parabolic membrane mirrors [6993-04]

T. Hellmuth, K. Khrennikov, Hochschule Aalen (Germany); W. Kronast, R. Huster,

U. Mescheder, Fachhochschule Furtwangen (Germany)

\section{SESSION 2 MOEMS DEVICES AND SYSTEMS II}

699306 New technologies for tunable micro-optics (Invited Paper) [6993-05]

Ch. Friese, A. Werber, F. Krogmann, R. Shaik, W. Mönch, H. Zappe, Univ. of Freiburg (Germany)

699307 Fabrication of polymer micro-optical components for integration in silicon MOEMS [6993-06]

D. Cristea, P. Obreja, M. Kusko, M. Purica, A. Dinescu, National Institute for Research and Development in Microtechnologies (Romania); A. Herrero, Fundación TEKNIKER (Spain); D. Apostol, National Institute for Lasers, Plasma and Radiation Physics (Romania); E. Manea, National Institute for Research and Development in Microtechnologies (Romania)

699308 Electrostatically-actuated grating light modulator fabricated using SU-8 photoresist [6993-07]

T. Aida, Y. Habu, T. Kato, Osaka City Univ. (Japan)

\section{SESSION 3 MICROFABRICATION AND MICROFLUIDICS I}

6993 OA Optofluidics and optoelectronic tweezers (Invited Paper) [6993-10] A. Jamshidi, A. T. Ohta, J. K. Valley, H.-Y. Hsu, S. L. Neale, M. C. Wu, Univ. of California, Berkeley (USA) 
6993 OB Micromachining of InP/InGaAs multiple membrane/airgap structures for tunable optical devices [6993-11]

T. Kusserow, S. Ferwana, Univ. of Kassel (Germany); T. Nakamura, T. Hayakawa, Canare Electric Co., Ltd. (Japan); N. Dharmarasu, Univ. of Kassel (Germany); B. Vengatesan, Canare Electric Co., Ltd. (Japan); H. Hillmer, Univ. of Kassel (Germany)

6993 OC Vacuum isostatic micro molding of microfluidic structures into polytetrafluoroethylene (PTFE) materials [6993-12]

T. E. Lizotte, Hitachi Via Mechanics USA Inc. (USA)

\section{SESSION 4 MICROFABRICATION AND MICROFLUIDICS II}

6993 OD Technology development for micromirror arrays with high optical fill factor and stable analogue deflection integrated on CMOS substrates (Invited Paper) [6993-13]

J.-U. Schmidt, M. Friedrichs, Fraunhofer IPMS (Germany); T. Bakke, SINTEF ICT (Norway);

B. Voelker, AEMtec GmbH (Germany); D. Rudloff, H. Lakner, Fraunhofer IPMS (Germany)

6993 OE Selective wet etching of AllnN layers for nitride-based MEMS and photonic device structures [6993-14]

I. M. Watson, C. Xiong, E. Gu, M. D. Dawson, Univ. of Strathclyde (United Kingdom); F. Rizzi, Italian Institute of Technology (Italy); K. Bejtka, P. R. Edwards, R. W. Martin, Univ. of Strathclyde (United Kingdom)

6993 OF Review of production of microfluidic devices: material, manufacturing and metrology [6993-15]

S. Li, Z. XU, Singapore-MIT Alliance (Singapore), Nanyang Technological Univ. (Singapore), and Singapore Institute of Manufacturing Technology (Singapore); A. Mazzeo, D. J. Burns, Massachusetts Institute of Technology (USA); G. Fu, Singapore-MIT Alliance (Singapore) and Nanyang Technological Univ. (Singapore); M. Dirckx, V. Shilpiekandula, Massachusetts Institute of Technology (USA); X. Chen, N. C. Nayak, Singapore-MIT Alliance (Singapore) and Nanyang Technological Univ. (Singapore); E. Wong, Massachusetts Institute of Technology (USA); S. F. Yoon, Singapore-MIT Alliance (Singapore) and Nanyang Technological Univ. (Singapore); Z. P. Fang, Singapore Institute of Manufacturing Technology (Singapore); K. Youcef-Toumi, D. Hardt, Massachusetts Institute of Technology (USA); S. B. Tor, C. Y. Yue, Singapore-MIT Alliance (Singapore) and Nanyang Technological Univ. (Singapore); J.-H. Chun, Massachusetts Institute of Technology (USA)

POSTER SESSION

$69930 G \quad$ Light concentrating micromirror arrays for photovoltaics [6993-08]

J. Ackermann, O. Setyawati, V. Viereck, N. Dharmarasu, H. Hillmer, Univ. of Kassel (Germany)

$6993 \mathrm{OH}$ A microelectromechanical force actuator for nano-tensile testing system [6993-16] S. Gao, K. Herrmann, Physikalisch-Technische Bundesanstalt (Germany) 
6993 Ol Feasibility study for a MEMS modulator suitable for optical system network signalling [6993-17]

P. Mitchell, Bookham Technology (United Kingdom); R. G. Jackson, J. K. Luo, Univ. of Bolton (United Kingdom)

6993 0J Determination of in-plane displacement of MEMS by means of an AFM sensor [6993-18] S. Gao, Z. Li, K. Herrmann, Physikalisch-Technische Bundesanstalt (Germany)

Author Index 
Downloaded From: https://www.spiedigitallibrary.org/conference-proceedings-of-spie on 25 Apr 2023

Terms of Use: https://www.spiedigitallibrary.org/terms-of-use 


\title{
Conference Committee
}

\author{
Symposium Chairs \\ Hugo Thienpont, Vrije Universiteit Brussel (Belgium) \\ Patrick P. Meyrueis, Université Louis Pasteur (France) \\ Giancarlo C. Righini, Istituto di Fisica Applicata Nello Carrara, CNR \\ (Italy) \\ Conference Chair
}

Hakan Urey, Koç University (Turkey)

Program Committee

Dan C. Dascalu, National Institute for Research and Development in Microtechnologies (Romania)

Padraig J. Hughes, SensL Technologies Ltd. (Ireland)

Marc J. Madou, University of California, Irvine (USA)

Yael Nemirovsky, Technion-Israel Institute of Technology (Israel)

Russell A. Noble, QinetiQ Ltd. (United Kingdom)

Minoru Sasaki, Toyota Technological Institute (Japan)

Harald Schenk, Fraunhofer-Institut für Photonische Mikrosysteme (Germany)

Ion G. Stiharu, Concordia University (Canada)

Henne van Heeren, EnablingM3 (Netherlands)

Session Chairs

1 MOEMS Devices and Systems I

Hakan Urey, Koç University (Turkey)

2 MOEMS Devices and Systems II

Yael Nemirovsky, Technion-Israel Institute of Technology (Israel)

3 Microfabrication and Microfluidics I

Hans Zappe, Albert-Ludwigs-Universität Freiburg (Germany)

4 Microfabrication and Microfluidics II

Cağlar Ataman, Koç University (Turkey) 
Downloaded From: https://www.spiedigitallibrary.org/conference-proceedings-of-spie on 25 Apr 2023

Terms of Use: https://www.spiedigitallibrary.org/terms-of-use 